\title{
ANALYSES OF THE STRESS INTENSITY OF THE CYLINDRICAL TANK WALL AT THE PLACE OF THE GEOMETRICAL DEFECT
}

\author{
Konstantin Rasiulis ${ }^{1}$, Kęstutis Gurkšnys ${ }^{2}$ \\ Vilnius Gediminas Technical University, Saulètekio al. 11, LT-10223 Vilnius, Lithuania \\ E-mail: ${ }^{1}$ rasiulis@vgtu.It; ${ }^{2}$ kestutis@vgtu.It \\ Received 21 Oct. 2009; accepted 18 Jan. 2010
}

\begin{abstract}
Major repair or regular inspection of the large capacity thin-walled tankages is very expensive. Steel cylindrical tanks are an individual case of the thin-walled tankages. The common calculation of the tanks by analytical and numerical methods is not difficult. Strengthening the places, where a perfect calculated form is disturbed, that is, at the spots of incuts, hatches, defects etc. is a responsible part of the design of such constructions. The problems of prevention of defects during the operation period and repairs, as well as possibility to assure quickly the safety of defective places of the constructions are more important than the common calculations. The main objective of the presented investigations is to identify stress/strain state of the wall tank with local imperfections from the ideal cylindrical surface, taking into account the membrane theory of the shells by using the finite element's method.
\end{abstract}

Keywords: tank, defect, stress concentration factor, regression analysis.

\section{Introduction}

Practical observations prove that accumulation of defects becomes the main reason of a failure if the tank is being used for 20 - 25 years (Rasiulis et al. 2006c). While developing the design standards the main attention was paid to the most dangerous "sharp" defects (holes, joints, cracks and so on) and the problem of local shape, "soft", defects (dents, bulges etc.) was not so important at this stage. In many cases, local shape defects, according to statistical investigations, are considered as secondary factors of various technical collapses. More importantly, the influence of such defects is observed in combination with poor-quality steel, near welded zones or next to the rigidity ribs (Gorochov et al. 2005; Maślak et al. 2008; Pircher et al. 2001). The "soft" defects are not investigated as widely as the "sharp" ones. The design codes and operating tanks in the USA, Europe and Russia limit the dimension of the "soft" defects during mounting and operation procedures. According to allowable deviations, the codes differently limit the sizes of "soft" defects (Table 1) (Aliphanov et al. 2004a, 2004b; ANSI/API Std. 650 1993; $\quad$ DIN 18800 1990; $\quad$ Eurocode 3 1999; CTO 0030 - 2004 2004; European Recommendations 1988). The allowances are very common and do not take into account the place of defects, thickness of the shell, radius etc. (Romanenko et al. 2004b). There parameter $f$ is a depth of the dent. It cannot exceed a definite percentage of the dent diameter. In the Eurocode (Eurocode 3 1999) the maximum deviation from a perfect form of the structure was proposed. It amounts to $1.6 \%$ of the dent diameter. In this case the structure is considered to be of a good quality, class "C". Accordingly, with smaller defect sizes the structure can be classified as the structure of a very good quality, class " $\mathrm{B}$ ”, or as the excellent quality structure, class “A”.

From the practical point of view and for more exact conclusions about mechanical state, near the defect minimum, two duplicated investigation methods should be applied. Bias of the experimental equipment as well as assumptions in the finite element analysis (FEA) methodology should be taken into account (Rasiulis et al. 2006b).

Practically, to study the influence of local shape defects on the thin walls of a tank, the descriptions of 84 cylindrical steel tank crashes have been investigated. In general, the most valuable 16 factors have been considered. This research has proved that the most important

Table 1. Allowable imperfections depend on design Code

\begin{tabular}{l|c|c}
\hline \multicolumn{2}{c|}{ Standard } & Allowance \\
\hline \multirow{2}{*}{$\begin{array}{l}\text { ENV 1993-1-6: } \\
\text { Eurocode 3 }\end{array}$} & A & $f \leq 0.6 \%$ \\
\cline { 2 - 3 } & B & $f \leq 1.0 \%$ \\
\cline { 2 - 3 } & C & $f \leq 1.6 \%$ \\
\hline API 650 & $f \leq 1.4 \%$ \\
\hline SNIP III-18-75 & $f \leq 1.0 \%$ \\
\hline DIN 18800 & $f \leq 1.0 \%$ \\
\hline
\end{tabular}




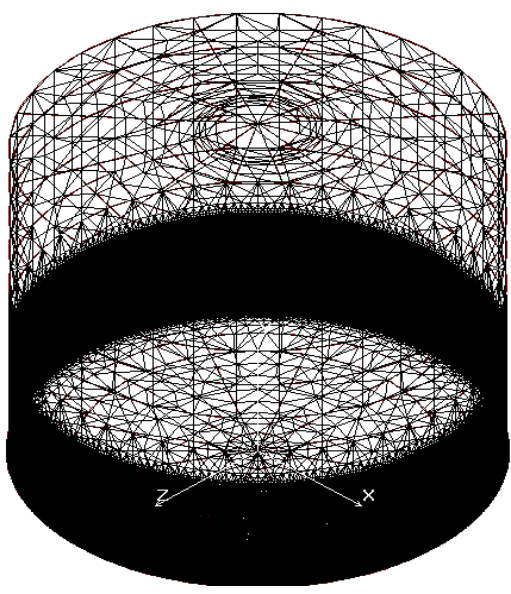

a)

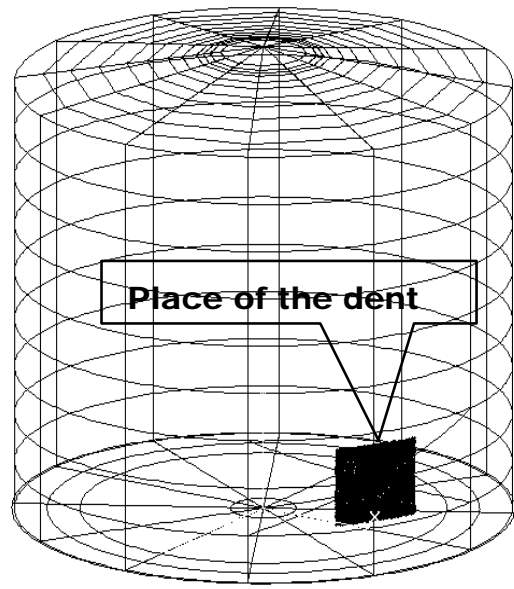

b)

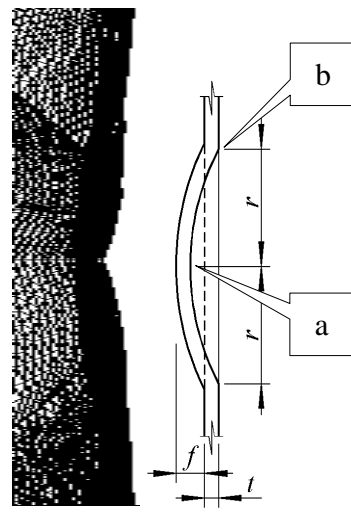

C)

Fig. 1. Volume 3D model of the tank: mesh of the finite elements (a), place of the defect (b), scheme of the defect (c)

errors may be as follows: the defects of the welded joints - in case 47 out of 84 failures of the cylindrical steel tank; the low temperature - in 28 out of 84 ; the disturbance in realization of a corresponding project - in 24 out of 84; the poor quality of the steel - in 25 out of 84; the stress concentration - in 16 out of 84; the differences of pressure - in 11 out of 84; the violation of the operating conditions - in 9 out of 84; the supports shrinkage - in 7 out of 84 ; the influence of the total corrosion - in 8 out of 84; the influence of the local corrosion - in 3 out of 84; the non-observance of the initial test conditions - in 7 out of 84; the defect of the form tank - in 3 out of 84; the residual stresses - in 2 out of 84; the fire - in 21 out of 84 ; the loss of the ductility - in 21 out of 84 ; the secondary damages - in 4 out of 84 (Aliphanov et al. 2002). In many cases, local shape defects can be described as an additional factor. On the other hand, this factor should be taken into account during the analysis of the mechanical behaviour of a geometrically non-perfect structure.

Besides, local shape defects are not considered to be an uncommon phenomenon. For example, an industrial complex of 78 thin-walled cylindrical tanks has been designed for light oil products. A great part of local geometric defects has been disclosed on the first (lowest) strip of the tanks (Aliphanov et al. 2002). Generally, 286 defects have been detected, 106 of which had the highest geometrical parameters in comparison with those limited by the standards: 95 dents and 11 bulges. In particular 41 dents and 3 bulges have been found on walls of $420 \mathrm{~m}^{3}$ volume tanks; 24 dents and 6 bulges - on walls of $700-3350 \mathrm{~m}^{3}$ tanks; 26 dents and 2 bulges - on $5000 \mathrm{~m}^{3}$ tanks; 4 dents - on the tanks of more than $5000 \mathrm{~m}^{3}$ volume (Aliphanov et al. 2002). On the other hand, practically a lot of tanks with defects exceeding those allowable by the standards are used. This fact, as it follows from observations, does not cause deterioration of the tank state (Rasiulis et al. 2006a).

Detection of more accurate dependences on allowable values factors and parameters of a specific tank in the analysed investigations is based on analytical rela- tions of the stress distributions, as well as on results of the observations of defects on the tanks used. Methods of the defects evaluation in pipes, as well as calculations of the stress concentration factors (SCF) on tensile plates were widely applied for getting formula for calculating SCF (Samsam Shariat et al. 2005). The most dangerous points for the dent are upper points "b" of its contour and its middle point "a” (Fig. 1c). The most dangerous SCF with "variable success" is available in the areas mentioned. The proposed formulas for the analysis of the wall's stress condition across the dent area are expressed by a polynomial with empirical factors. In this case, in contrast to the codes, the influence of the thickness $t$ and radius $R$ of the tank wall is taken into account; besides, the principal differences between middle and contour points are indicated (Rasiulis et al. 2006a). The results of analysing the stress condition of the tank wall of specific capacity with initial parameters $R=11.5 \mathrm{~m}, H=12.0 \mathrm{~m}$ and $t=7.0 \mathrm{~mm}$ are different, when the methods considered are used (Rasiulis et al. 2006a). It is obvious that the methods are not perfect enough and opinions concerning investigation of the given object are also different. It should be noted that all formulas take into account elastoplastic deformations of the material.

\section{Numerical model}

The modelling of defect for a real structure has been performed. In this case the main solutions are made by using standard finite element code COSMOS/M (Fig. 1a, 1b) (Barauskas 2004; Cosmos/M 2002; Juozapaitis et al. 2008; Saide 1993).

For modelling the problem by $\operatorname{COSMOS} / \mathrm{M}$, a whole cylindrical tank was taken and loaded by the diesel oil pressure (load_2) from within, by snow load (load_4), wind load from right to left and from left to right (load_8 and load_9 respectively) (Greiner et al. 1995), vacuum load (load_6), additional pressure of the evaporation of diesel oil (load_7), plus temperature load (load_11) and minus temperature load (load_12). The tank parameters were as follows: diameter $R=15.2 \mathrm{~m}$, height $H=12.0 \mathrm{~m}$ and the wall thickness at a site of the defect $t=6.0 \mathrm{~mm}$. 


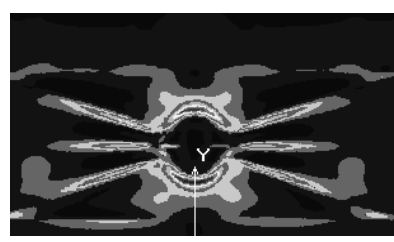

a)

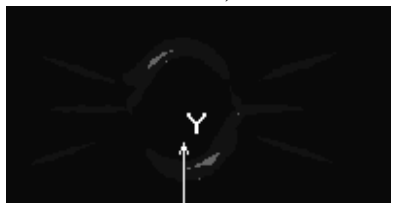

e)

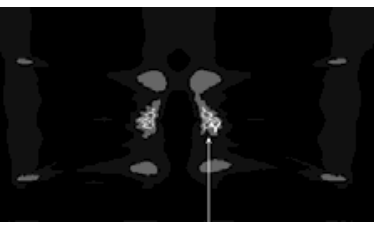

b)

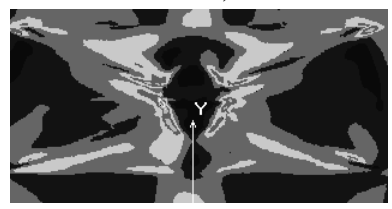

f)

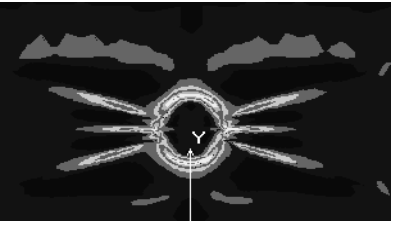

C)

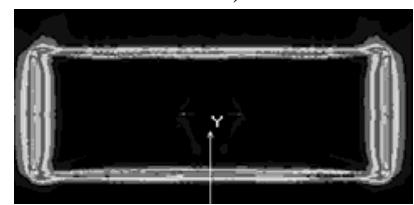

g)

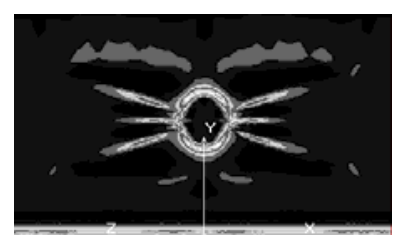

d)

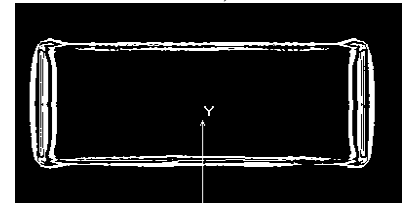

h)

Fig. 2. The distribution of the von Mises stresses next to a defect due to: load 2 (a), load 4 (b), load 6 (c), load 7 (d), load 8 (e), load 9 (f), load 11 (g) and load 12 (h)

Finite elements (FE) of "SHELL" type having 3 nodes and described by 18 degrees of freedom (DOF) were employed during this calculation (3 linear displacements and 3 rotational displacements at each node of FE mesh). In order to simulate the real situation ground pressure on the tank bottom was considered as conventional rigidities of 6.0 $\mathrm{MPa}$ on the middle part of the bottom tank and 7.0 MPa on the contour part of the bottom tank. The model created in COSMOS/M reflects natural location of a dent on the lower strip of the entire tank (Fig. 1). The tank has been subjected to self-weight in every case of the loads.

\section{Calculation of the stresses intensity taking into account real loads during exploitation period}

In the presented research the strength of the lower strips of the tank wall has been considered. In case of common calculations of the tank, wall thickness of lower strips are determined more frequently by the strength condition.

At this stage of investigation the defect influences on the wall strength of the tank, distribution of the intensity stresses, have been analyzed in the area of the tank defected part at different peculiar loads during service. The loads were described in the previous chapter. From the presented results (Fig. 2, 4) it is obvious, that those real loads have different influence on the place of maximum stresses. The distribution of the stresses within the lower strip of the tank wall (Fig. 1b) is presented in the Fig. 2. The analyzed scheme of the tank wall part was showed in showed in Fig. 3. In agreement with the calculation results it is definitely clear, that in case of uniformly distributed loads directed normally to tank wall, the maximum stresses are usually placed on the contour of the upper and lower parts of the defect, respectively from the side of the tank roof and bottom (Fig. 2a, c, d, e, f). In case of the snow load, the maximum stresses are located also across contour part of the dent only on sides of the defect (Fig. 2b). The lighter zones of the diagrams show the stress concentration. With an increase in colour to light grey the stress concentration accepts maximum values. The dark colours show a decrease in intensity stresses to nominal ones in case of a black colour. It should be noted, that stresses concentration in case of temperature loads is situated next to defect area (Fig. 2g, h). Further, on the next diagrams (Fig. 4a, b, c) stresses distributions from the upper contour part of the dent to its middle portion were presented. The scheme of the defect is shown in Fig. 3, line 1-1. At temperature loads the line 2-2 represents a more interesting place (Fig. 3). On the ordinate axis of the diagram (Fig. 4), relative stresses are marked. They are equal to relation between intensity stresses on the shell of the tank wall and yield strength, $\sigma / f_{y, d}$. On the abscissa axis of the diagram distances between nodes are marked.

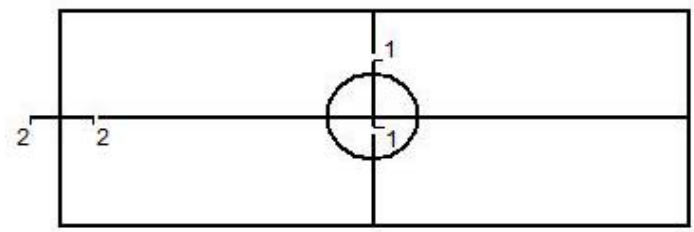

Fig. 3. The scheme of the defect place

According to the diagrams, the stress concentration always exists on the contour of the dent in all cases of the loads. In case of temperature loads, the stress concentration is more dangerous in a zone near defect, than on the dent (Fig. 2g, h, 4d).

The stored product pressure in case of the tank full filling has more influence on stress concentration within the defects area (Aliphanov et al. 2004c; Rasiulis et al. 2006d; Romanenko et al. 2004a).

\section{Calculation of the stress concentration factor taking into account the linearity of the numerical model}

Further in this part of the research, the distribution of the SCF depending on dent sizes $\beta$ and $\gamma$ is analysed (Fig. 5).

The relative radius of the dent $\beta$ expresses a conventional dimension of an across of the tank shell:

$$
\beta(r, R, t)=\frac{r}{\sqrt{R \times t}},
$$

where $r$ is a dent radius, $R$ is a radius of the whole tank, $t$ - the tank shell thickness at a site of defect. The $\gamma$ describes a relative sag of the thin shell:

$$
\gamma(f, t)=\frac{f}{t}
$$

where $f$ is an absolute value of the sag, i. e. the greatest deviation from a perfect form at the defect location. 


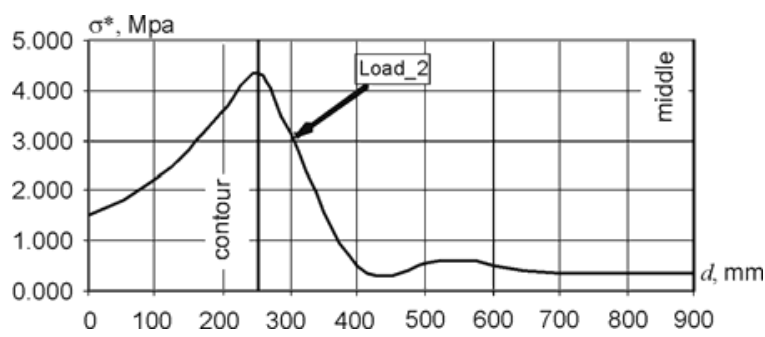

a)

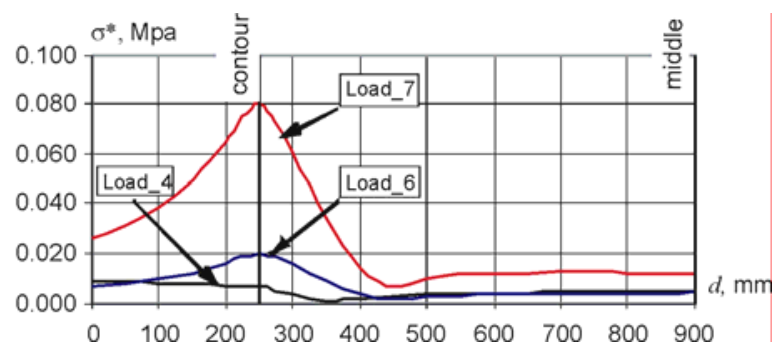

b)

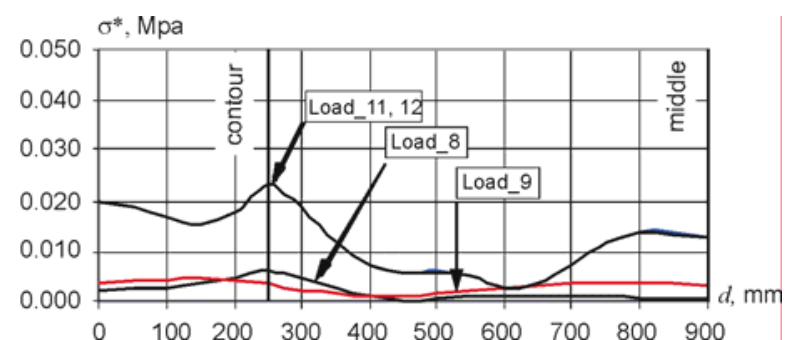

c)

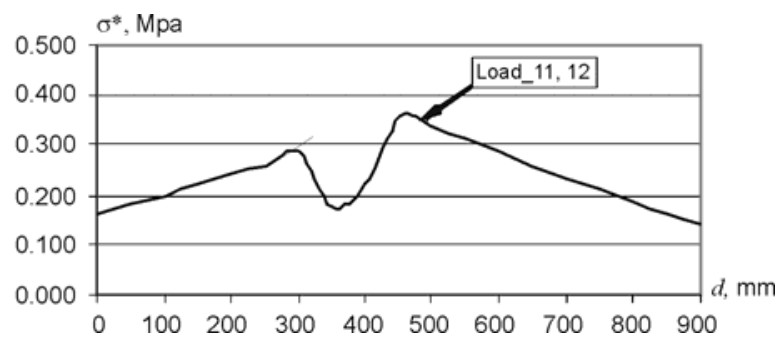

d)

Fig. 4. The diagrams of disribution of the relative stresses in the defect place of the tank wall in case: load 2 (a), load 4, 6, 7 (b), load 8, 9, 11, 12 (c) and load 11, 12 (d)

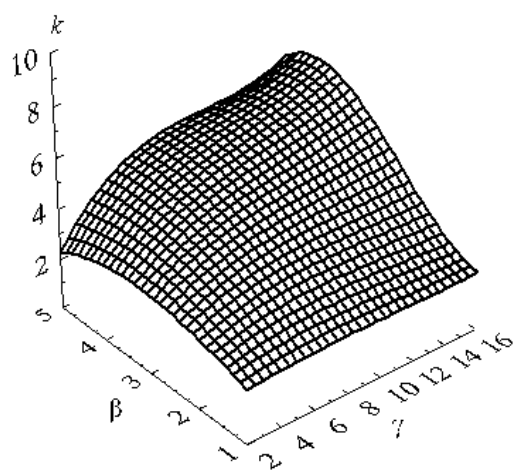

a)

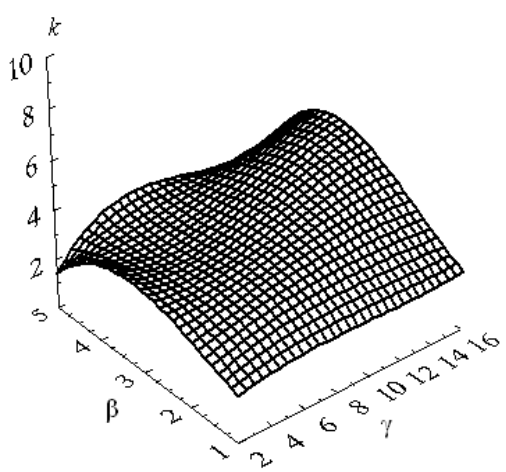

b)

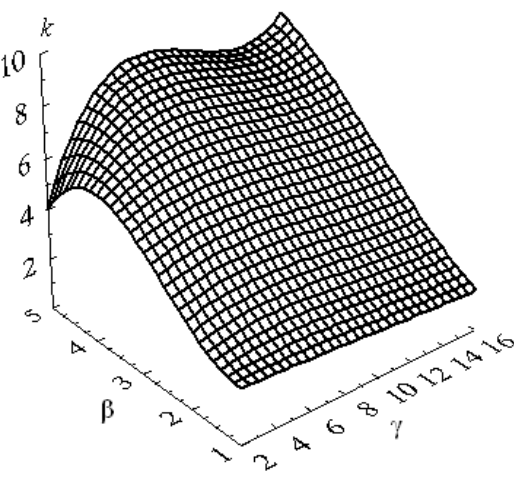

c)

Fig. 5. The SCF dependence between depth $\gamma$ and radius $\beta$ of the defect: semisphere (a), cone (b) and truncated cone (c)

The cylindrical tank was loaded by the diesel oil pressure (load_2) from within.

A large number of calculations, using the FEM, provides an exact analysis of the results. These results were accumulated in the data file to perform the regression analysis. The SCFs have been analyzed for the most dangerous point of the dent " $b$ ". As the SCF dependence on the dent shape, its sizes, depth and radius is non-uniform, it is advisable to use polynominal regression.

The polynominal function of the $3^{\text {rd }}$ degree was used to obtain the relationship between SCF and the defect sizes. The given function for the data obtained requires the data file sufficiently precise to an accuracy of 98-99\%. The polynominal function of the $3^{\text {rd }}$ degree describing relation between SCF and geometry of the defect and its shape is presented as follows:

$$
\begin{aligned}
k(\gamma, \beta)= & b_{1}+b_{2} \gamma+b_{3} \beta+b_{4} \gamma \beta+b_{5} \gamma^{2}+b_{6} \gamma^{2} \beta+b_{7} \beta^{2}+ \\
& b_{8} \gamma \beta^{2}+b_{9} \gamma^{2} \beta^{2}+b_{10} \gamma^{3}+b_{11} \gamma^{3} \beta+b_{12} \gamma^{3} \beta^{2}+ \\
& b_{13} \beta^{3}+b_{14} \gamma \beta^{3}+b_{15} \gamma^{2} \beta^{3}+b_{16} \gamma^{3} \beta^{3} .
\end{aligned}
$$

The function is plotted in Fig. 5.

\section{Elasto-plastic calculation}

The calculation results of the tank wall, having a „soft“ defect with different grades of steel, are given in this chapter. As the calculation result, SCF have been obtained, and the data analysis was performed accordingto the calculation results. For SCF calculation COSMOS/M was employed. Processing the results was made by means of "STATISTICA" software. The tank wall with a geometrical semi-spherical defect was calculated, the tank radius being $R=11.5 \mathrm{~m}$, its height $H=12.0 \mathrm{~m}$, the wall thickness at a site of the defect was $t=7.0 \mathrm{~mm}$, its relative depth $2 \leq \gamma \leq 16$, the defect relative radius $1 \leq \beta \leq 5$. The results have been fixed in the most dangerous upper point „, b“ of the dent contour. In the FEM program diagrams $\sigma-\varepsilon$ were specified for the steels of grade ВСтЗГпс, 09Г2 and 15Г2СФД (Table 2). The modified Newton-Raphson force control method for geometrically non-linear calculations was used (Cosmos/M 2002; Saide 1993). For physical nonlinearity the diagram of the elasto-plastic material with strengthening in a plastic part was applied (Cosmos/ M 2002; Saide 1993). When analysing the stresses and 


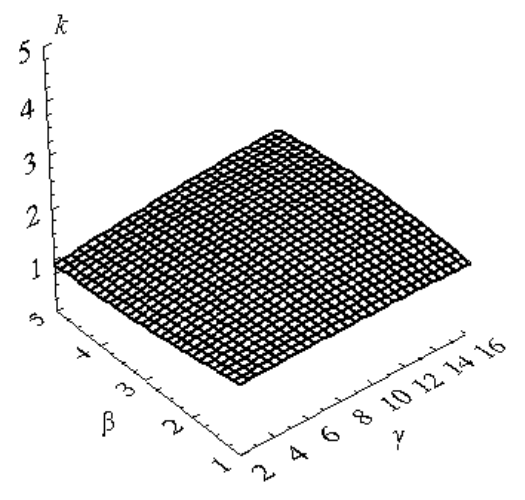

a)

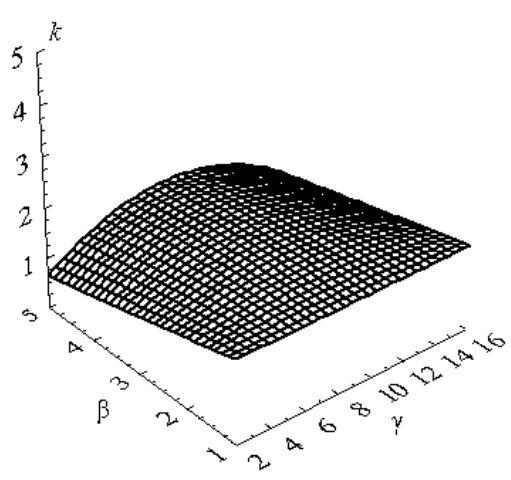

b)

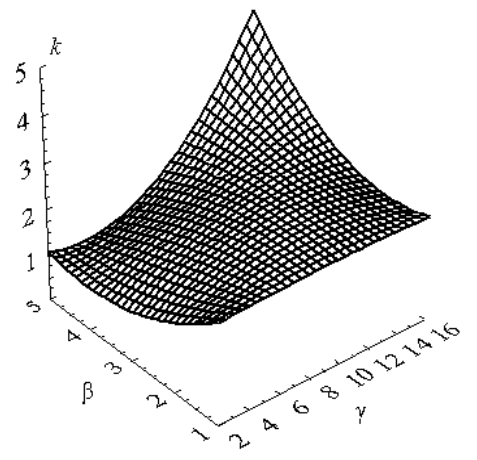

c)

Fig. 6. The SCF dependence on geometrical sizes of semi-spherical dent in the upper point of its contour, when the metal grade of ВСтЗГпс (a), 09Г2 (b), 15Г2СФД (c) is used

Table 2. Nominal values of the mechanical properties of the steels

\begin{tabular}{lccccc}
\hline \multicolumn{1}{c}{ Steel grade } & $\sigma_{0.2}$, & $\varepsilon_{y}$ & $\sigma_{u}$, & $\varepsilon_{u}$ & $\psi$ \\
& MPa & & MPa & & $\%$ \\
СтЗГпс & 245 & 0.00118 & 370 & 0.26 & 58.0 \\
09Г2 & 305 & 0.00148 & 440 & 0.21 & 40.0 \\
15Г2СФД & 420 & 0.00203 & 590 & 0.18 & 37.0 \\
\hline
\end{tabular}

displacements across the defect area, the relative appropriate size of the finite element is $\zeta=7.1$ (Rasiulis et al. 2006a). In order to determine the finite element optimum size the results of the numerical calculations of the tank wall with the dent have been analysed (Rasiulis et al. 2006a). As a result, one obtained two relationships between value of relative circular stresses $\sigma^{*}$ and finite element sizes $\zeta$ as well as between relative displacements $\mathrm{u}^{*}$ and finite element sizes $\zeta$ at the typical points of the dent (Rasiulis et al. 2006a). Additionally, for checked numerical model, distribution of the normal stresses in the cross-section of the thin steel plate with a geometrical defect was analysed by natural experiment and finite element's method by using standard FEM program COSMOS/M (Rasiulis et al. 2006d).

The plots (Fig. 6) show the results of SCF depending on geometrical sizes of the dent. The diagrams of SCF dependences illustrate that with different grades of steel the dependence of SCF on the dent geometry is different. In case of steels of lower grade having good ductility (when in the standard tension experiment the cross-section reduction of a sample is about $\psi=60 \%$ ), SCF does not considerably depend on the defect sizes. Then SCF may be accepted as $k=1.6$ in all cases of the defect geometry (Fig. 6a). Further, increasing during calculations the steel grade one observes a more obvious dependence of SCF values on the defect geometrical parameters due to more limited ductility of the steel (when in a standard tension experiment, the cross-section reduction of the sample is about $\psi=40 \%$ ). Therefore in cases of a higher grade of the steel, the SCF dependence on the defect geometry must be taken into consideration. For steels with $\psi<40 \%$, the SCF dependence on the defect sizes is increased. To an equal degree SCF becomes very dangerous in the upper point of the dent contour in case of sharp defects.

Further, the regression analysis of the SCF data obtained was carried out by using the method of the least squares. The SCF calculation function depending on the defects parameters and steel of the tank wall has been obtained:

$$
k=b_{1}+\left(b_{2} \gamma+b_{3} \beta+b_{4} \frac{\sigma_{0.2}}{\sigma_{u}}+b_{5} \gamma \beta \frac{\sigma_{0.2}}{\sigma_{u}}\right)^{b_{6}},
$$

where $\gamma$ - relative defect depth, $\beta$-defect relative radius, $\sigma_{0,2}$ - conventional yield strength, $\sigma_{u}-$ temporal breaking strength (tensile strength), $b_{i}$ - empirical coefficient. The accuracy results of this function makes up $88,6 \%$ of the results obtained using the FEM.

\section{Conclusions}

The stored product pressure in case of the tank full filling has more influence on stress concentration within the defected area.

The maximum stresses of the linear calculations are disposed on the dent contour, and maximum SCF is $k=8.52$ when $\gamma=7, \beta=5$.

The maximum stresses of the non-linear calculations are also located on the dent contour and maximum SCF is $k=1.6$ for steels with $\psi \geq 60 \%$ when $\gamma=16, \beta=5$ and $k=4.5$ for steels with $\psi \leq 40 \%$ when $\gamma=16, \beta=5$.

The diagrams of SCF dependences illustrate that with different grades of steel the dependence of SCF on the dent geometry is different. In case of steel of lower grade having good ductility (when in the standard tension experiment the cross-section reduction of a sample is about $\psi=60 \%$ ), SCF does not considerably depend on the defect sizes. Therefore in cases of a higher grade of steel, the SCF dependence on the defect geometry must be taken into consideration. For steels with $\psi<40 \%$ the SCF dependence on the defect sizes is increased. To an equal degree SCF becomes very dangerous in the upper point of the dent contour in case of "sharp" defects. 


\section{References}

Aliphanov, L. A.; Moskvichev, V. V. 2002. The mode of deformation of storage tanks with shape defects, Computation Technology 7: 16-22.

Aliphanov, L. A.; Romanenko, K.; Moskvichev, V. V.; Lepikhin, A. M.; Samofalov, M. 2004. Analysis of geometrical shape defects of a steel cylindrical tank wall by numerical and analytical methods, in Abstracts of the 8th International Conference "Modern Building Materials, Structures and Techniques”, Vilnius, Lithuania, 2004. Vilnius: Technika, 287-288.

Aliphanov, L. A.; Romanenko, K.; Moskvichev, V. V.; Lepikhin, A. M.; Samofalov, M. 2004. Analysis of geometrical shape defects of a steel cylindrical tank wall by numerical and analytical methods, in Proc of the 8th International Conference "Modern Building Materials, Structures and Techniques”, Vilnius, Lithuania, 2004. Vilnius: Technika, 334-342.

Aliphanov, L. A.; Romanenko, K; Samofalov, M. 2004. FEM application in geometrically non-linear analysis of local shape defects on steel cylindrical tank walls, in International conference "17th Nordic Seminar on Computational Mechanics”, Stockholm, Sweden, 2004. Stockholm, 90-93.

ANSI/API Std. 650, American National Standard: Welded Steel Tanks for Oil Storage. Final draft, 1993. 182 p.

Barauskas, R.; Belevičius, R; Kačianauskas, R. 2004. Baigtiniu elementu metodo pagrindai [Basis of the finite elements method]. Vilnius: Technika. $612 \mathrm{p}$.

COSMOS/M. User's Guide. 2002. 1289 p.

DIN 18800: Stahlbauten. Stabilitätsfalle, Schalenbeulen [Steel structures. Buckling failure of the shell]. 1990. 248 p.

Eurocode 3: Design of steel structures. Part 1-6: General rules. Supplementary rules for the shell structures. Brussels, 1999. $82 \mathrm{p}$.

European Recommendations For Structural Stability. ECCSTechnical Committee 8, Technical Working Group 8.4: Buckling of steel shells, stability of shells. Brussels, 1988. $82 \mathrm{p}$.

Gorochov, Y.; Muschanov, V.; Kulik, A; Tsyplukhin, A. 2005. Vertical cylindrical tank with angular geometrical imperfection, Journal of Civil Engineering and Management 11(3): 175-183.

Greiner, R.; Derler, P. 1995. Effect of imperfections on windloaded cylindrical shells, Thin-walled Structure 23: 271-281. doi:10.1016/0263-8231(95)00016-7

Juozapaitis, A; Kutas, R; Jatulis, D. 2008. Mast behaviour analysis and peculiarities of numerical modelling, Journal of Civil Engineering and Management 14(1): 61-66. doi:10.3846/1392-3730.2008.14.61-66
Maślak, M; Siudut, J. 2008. Deterioration of steel properties in corroded sheets applied to side surface of tanks for liquid fuels, Journal of Civil Engineering and Management 14(3): 169-176. doi:10.3846/1392-3730.2008.14.13

Pircher, M.; Berry, P. A.; Ding, X.; Bridge, R. Q. 2001. The shape of circumferential weld-induced imperfections in thin-walled steel silos and tanks, Thin-walled Structure 39: 999-1014. doi:10.1016/S0263-8231(01)00047-7

Rasiulis, K.; Samofalov, M; Šapalas, A. 2006. Application of the non-linear fe models to estimate effect of soft defects on thin walls of steel cylindrical tanks, Journal of Civil Engineering and Management 12(2): 169-179.

Rasiulis, K.; Samofalov, M; Šapalas, A. 2006. Stress and strain state investigation of soft defects on thin steel plate using experimental and numerical methods, Mechanika 59(3): 5-13.

Rasiulis, K.; Šapalas, A.; Vadlūga, R.; Samofalov, M. 2006. Stress/strain state investigations for extreme points of thin wall cylindrical tanks, Journal of Constructional Steel Research 62: 1232-1237. doi:10.1016/j.jcsr.2006.04.016

Rasiulis, K.; Samofalov, M.; Šapalas, A. 2006. Stress strain state investigation of soft defects on the thin steel plate by using experimental method, in Proceedings of the 11th international conference "Mechanika 2006", Kaunas, Lithuania, 2006. Kaunas: Technologija, 283-288.

Romanenko, K.; Samofalov, M.; Šapalas, A; Aliphanov, L. A. 2004. Linear and physical non-linear stress state analysis of local shape defects on steel cylindrical tank walls by the finite element method, Mechanika 2(46): 5-13.

Romanenko, K.; Šapalas, A.; Kvedaras, A. K.; Samofalov, M. 2004. Physical and geometrical non-linearity in stress/strain state FE analysis of thin walled structures, in International conference "17th Nordic Seminar on Computational Mechanics”, Stockholm, Sweden, 2004. Stockholm, 179-182.

Saide, P. 1993. Theoretical Manual for COSMOS/M. Santa Monica, California: Structural Research and Analysis Corporation. 160 p.

Samsam Shariat, B. A.; Javaheri, R.; Eslami, M. R. 2005. Buckling of imperfect functionally graded plates under in-plane compressive loading, Thin-walled Structures 43: 1020-1036. doi:10.1016/j.tws.2005.01.002

СТО 0030-2004: Резервуары вертикальные иилиндрические стальные для нефти и нефтепродуктов. Правила технического диагностирования, ремонта $u$ реконструкиии [The vertical cylindrical steel tanks for oil and oil products. The rules of the diagnostics, repair and reconstruction]. Москва, 2004. 43 p. 


\section{CILINDRINE்S TALPYKLOS SIENELE்S SU GEOMETRINĖMIS NUOKRYPOMIS IৃTEMPIŲ IR DEFORMACIJŲ BŪVIO ANALIŻ்}

\section{K. Rasiulis, K. Gurkšnys}

\section{Santrauka}

Didelio tūrio statinių remontai arba net profilaktinės apžiūros yra gana brangūs procesai. Metalinės cilindrinės talpyklos priskiriamos prie atskiros tūrinių plonasienių konstrukcijų grupès. Talpyklų reguliarių konstrukcijų analitiniai ar skaitiniai skaičiavimai nėra sudètingi. Bet tokių vietu, kaip konstrukcijų jungčių bei technologinės įrangos prijungimo projektavimas ar konstrukcijų defektų analizė yra gerokai svarbesnė projektavimo dalis. Defektų prevencija naudojant talpyklas, taip pat defektuotų vietų sustiprinimas yra svarbesnis nei bendrieji talpyklų skaičiavimai. Šio darbo tikslas - nustatyti realaus objekto cilindrinès talpyklos sienelès su geometrinėmis lokaliomis nuokrypomis itempių ir deformacijų būvị pagal membraninę kevalų skaičiavimo teoriją, taikant baigtinių elementų metodą.

Reikšminiai žodžiai: plieninė cilindrinė talpykla, defektas, skaitinis modelis, baigtinis elementas, ịtempių ir deformacijų būvis.

Konstantin RASIULIS. Doctor, Assoc. Professor of Dept of Steel and Timber Structures of Vilnius Gediminas Technical University. Field of research: finite element method, design and numerical modeling of tank defects, engineering software for Civil Engineering, inspection of real industrial processes.

Kęstutis GURKŠNYS. Doctor, Assoc. Professor of the Dept of Steel and Timber Structures of Vilnius Gediminas Technical University. Field of research: timber and timber-concrete composite structures. 